Marquette University

e-Publications@Marquette

Spanish Languages and Literatures: Research and

Publications

Foreign Languages and Literatures

$1-1-2014$

Picturesque Violence: Tourism, the Film Industry, and the Heritagization of 'Bandoleros' in Spain, 1905-1936

Eugenia Afinoguénova

Marquette University, eugenia.afinoguenova@marquette.edu

Eduardo Rodríguez Merchán

Universidad Complutense de Madrid

Accepted version.Journal of Tourism History, Vol. 6, No. 1 (2014): 38-56. DOI. (C) 2014 Taylor \& Francis (Routledge). Used with permission. 


\title{
Picturesque Violence: Tourism, The Film Industry, And The Heritagization Of 'Bandoleros' In Spain, 1905-1936
}

\author{
Eugenia Afinoguenova \\ Foreign Languages and Literatures, Marquette University \\ Milwaukee, WI
}

\begin{abstract}
This article examines the debates about the Andalusian 'bandoleros' (bandits) in the context of early tourism as a state-guided policy in Spain. As we argue, the development of tourism made Spanish intellectuals reconsider the real armed activity in Andalucía as part of Spanish national heritage and a tourist attraction. Consistent with the stereotypical image of Spain coined by the Romantic travelers, such an early heritagization of brigandry reveals the role of the élites in recasting exotic imagery into modern tourism-shaped identities: in the hands of early-century writers, bandits were reshaped as part of the 'modern picturesque'. Furthermore, the role given to brigands in early cinema allows one to see how the early heritage discourse bridged transnational and centralist interests at the expense of the regional ones, thus foreshadowing the debates about hegemony in present-day heritage studies.
\end{abstract}

Keywords: Spain, 1900-1936; 'bandolero'; banditry; tourism; travel; film; Andalucía, image of. 


\section{A pre-history of heritage tourism}

In the summer of 2013, hoping to bring travelers into the areas that have so far remained on the margins of the tourism industry, Catalonia launched a new product called 'Tourism Competitiveness Plan "Woods of Witches and Bandoleros".' Although this was not the earliest reinvention of brigands as an 'endangered heritage [el patrimonio que está en peligro de desaparecer]' for tourism purposes, it was the first to be created with government participation.i In 2010, when the central and Catalan authorities embarked on the project, there already existed an example developed by a private entity in Andalucía, the 'Land of José María el Tempranillo Foundation'. iii It offered a well-endowed permanent exhibition called 'Romantic banditry interpretation center' in Jauja, the town in the Córdoba province that was the cradle of the man immortalized as Don José in Prosper Merimée's Carmen (1845) and his numerous incarnations on stage and on film. This bandit product was firmly grounded in more than ten years of scholarly research collected during the annual conferences dedicated to Andalusian brigandry and published by the same foundation. iv $^{2}$

The bandoleros were so popular among nineteenth-century travelers that their recent comeback is unsurprising. Rather, it is strange that it has taken so long for them to be reinvented as a tourist attraction. In comparison, the Robin Hood Trail in the Sherwood Forest has been a commercialized tourist attraction since, at least, the 1990s, ${ }^{v}$ although that legendary brigand had never fascinated

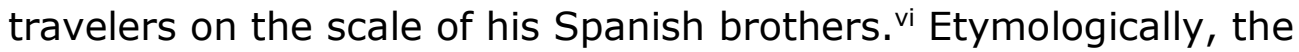
word 'bandolero' referred specifically to fugitives from justice whose names were printed on 'Wanted' posters, called 'bandos', displayed on the doors of city halls and churches. These robbers formed groups called, in Spanish, 'partidas' that settled away from the inhabited areas. ${ }^{\text {vii }}$ In Catalonia, however, the word 'bandoler' had a different usage and was reserved for the protagonists of social revolts, family feuds, and separatist movements. In Andalucía, armed robbers were already documented in the Roman and medieval times and in Catalonia in the seventeenth century, when the nobleman Don Joan Sala i Serrallonga tried to defend local privileges against King Philip IV's centralizing attempts.viii Since 1770, the dictionaries of Spanish 
Royal Academy have listed 'bandolero' and 'bandido [bandit]' as synonyms, defining the former as 'robber and highwayman'.

After the Peninsular War (1808-1814), which made 'guerilla' a familiar word in French and English, meetings with 'bandoleros' became a plot-moving device that fueled the burgeoning travelogue markets in Britain, France, and the United States. ${ }^{\text {ix }}$ In 1842, the Englishman Richard Ford, whose well-informed books denounced the scenes depicting the travelers' meetings with bandoleros as cheating, called the 'banditti' an export commodity: 'the stimulant ... not less necessary for the established taste of the home-market, than brandy is for pale sherries neat as imported'. ${ }^{x}$ In 1862 , confessing that the 'thorough' security of the Spanish roads was making him fantasize about 'a slight encounter with bandits', Hans Christian Andersen alleged that the famous French writer Alexandre Dumas had even tried to arrange to be robbed in Andalucía by sending a 'well-known robberchief' a check for a thousand francs prior to his visit in 1845 . The brigand replied that he had retired from business but enclosed a receipt for the check he cashed, thus de facto robbing Dumas, albeit in an unscripted way. ${ }^{\mathrm{xi}}$

In the twentieth century, the term 'bandolero' acquired an array of meanings related to class violence in Spain's periphery while also losing its separatist connotations. In 1917, the philologist José Alemany y Bolufer coined the word 'bandolerismo' to denote 'large numbers of bandoleros in a region or a province'. xii Although Alemany might well have had in mind the anarchist rebellions in Catalonia, early twentieth-century debates about the heritagization of bandoleros were concerned exclusively with Andalucía, where anarchist-led armed revolts were on the rise. Spanish Royal Academy's 1936 Diccionario histórico even expanded the meaning of 'bandolerismo' to include 'violent acts committed by bandoleros'. xiii Although our article will focus on this later terminology, it is important to remember that the recasting of class struggle in Andalucía as a folkloric 'bandolerismo' also implied a systematic silencing of the anti-centralist thread of armed violence rooted in Catalonia.

If bandoleros were so popular among the nineteenth-century lone travelers and their readers, why did Spain's tourism authorities neglect this treasure for so long? As this article argues, the history of brigand heritage in Spain really began in the early twentieth century, 
when the liberal elites seeking to expand active citizenship developed an interest in tourism. When the state got involved in this new industry (1905), many wondered how, if at all, Spain's reputation as an exotic, danger-ridden land could fit with the image of a successful nation that the government was seeking to project. xiv Andalusian brigands competed with Carmen for the dubious merit of symbolizing Spain's pre-modern, 'picturesque' appeal; yet unlike Carmen, armed bandits were not only fictional, but also real. How could the authorities capitalize on this dangerous attraction while also assuring foreign and domestic populations that they cared for safety? As state officials, educated Spaniards could not but wish for the banditry to be eradicated. As private individuals, however, they were curious about bandits as subjects worth recreating for tourism purposes. The solution they found for this dilemma-conjuring an image of an 'ethnographic bandit' that supposedly had nothing to do with class warfare-reveals how deeply the social debate about tourism changed the ways in which Spaniards approached their domestic affairs.

According to Gregory John Ashworth's influential model, heritage is a cultural product that treats material and non-material culture as its resource. Our analysis, however, is grounded in Laurajane Smith's take on this concept: 'there is, really, no such thing as heritage'.xv Rather, the objects and practices of the past deemed worthy of being protected and publicized become 'heritage' through an ongoing process of social encoding and legitimating that Smith calls 'Authorized Heritage Discourse'. While heritage products and sites, as well as alternative heritage discourses, reflect the conflicts behind the social consensus, the Authorized Heritage Discourse is called on to naturalize the values and interests of the hegemonic classes. Such an approach to heritage as a debate, rather than a product, opens the door to analyzing intellectual pursuits that may not culminate (or may not culminate immediately) in recognizable products. ${ }^{x v i}$ In our example, criminalist inquiry, early tourism, the press, and film complemented each other in enabling Spaniards to think about bandits as an attraction decades before the first bandit heritage sites began to emerge. This early packaging of the pre-modern exotic for the present-day transnational markets provides a missing link to many heritage phenomena of our time.

Journal of Tourism History, Vol 6, No. 1 (2014): pg. 38-56. DOI. This article is @ Taylor \& Francis (Routledge) and permission has been granted for this version to appear in e-Publications@Marquette. Taylor \& Francis (Routledge) does not grant permission for this article to be further copied/distributed or hosted elsewhere without the express permission from Taylor \& Francis (Routledge). 
As the Spanish example suggests, even when tourism was failing to become a successful industry, the debates about it succeeded in making the reading and writing public look at themselves and their compatriots with a foreigners' eye. The elite's enthusiasm for the new industry thus brought the 'tourist gaze'xvii home and turned it into a vehicle of domestic politics. Commenting on the Carmen characters in early cinema, José Colmeiro remarks that, while the citizens of modern European nations were projecting onto less developed countries such as Spain their notions of the primitive and the authentic, 'Spain's position in this process was singular and contradictory, for as an integral part of European culture it participated in this exotic venture in search of the picturesque, at the same time that its own eccentric cultural construction was highly mediated by orientalism'. ${ }^{\text {xviii }}$ The debates about brigands make it clear that the elites mediated in this translational and domestic 'othering' of Spain by proposing new avenues for adapting the picturesque for modern needs.

The government, of course, did not declare brigands a protected species. Yet, as we shall see, the rebranding of bandits affected the coverage of real criminal activity. When it became clear that bandits were an international currency that tourism officials would not put to use, another new industry-cinema-jumped on the international image-making locomotive. In the 1910s-1930s, Spanish and foreign film directors competed to create the best Spanish brigand, thereby creating a whole gallery of them. The directors' success gives us a glimpse of a transnational heritage product that, albeit in a form of a celluloid illusion, thrived in the early twentieth century.

\section{The state, early tourism and the bandits}

One can argue that the view of heritage as a usable present crafted for domestic consumption from state-owned relics was merely a short stop on the road between two more important and lasting mindsets: a cosmopolitan quest for the roots of Western Civilization and a transnational longing for the authentic outside of one's country of origin. In Europe, the era of transnational heritage discourse-a domestic public debate about the tourism potential of certain national customs and artifacts-emerged when governments became involved

Journal of Tourism History, Vol 6, No. 1 (2014): pg. 38-56. DOI. This article is @ Taylor \& Francis (Routledge) and permission has been granted for this version to appear in e-Publications@Marquette. Taylor \& Francis (Routledge) does not grant permission for this article to be further copied/distributed or hosted elsewhere without the express permission from Taylor \& Francis (Routledge). 
in the tourism business. Yet for most part, national heritage markers hailed from different parts of nation-states that 'nationalized' them through the monument commissions, academies, and other relevant institutions. Bandits were one such product, deeply linked to Andalucía.

Since the nineteenth century, this region had projected an image of extreme backwardness, while its Arab architecture and its proximity to Africa made it the primary destination for foreign (especially, British) travelers. So, although prior to the seventeenth century bandoleros were known in Catalonia and Madrid (Luis Candelas), the modern tradition of bandits was firmly maintained by Andalusian armed robbers. Following Eric Hobsbawm's model of social banditry, ${ }^{\text {xix }}$ Timothy Mitchell explains how the bandit's class-bending character got blended into the wider picture of 'tragic Andalucia', where all social groups, not just the poor, experienced some sort of oppression within the shifting geography of power inside Spain. ${ }^{x x}$ Responding to these theories, Ben Dodds has recently demonstrated that, in the mid-nineteenth century, while the narratives about Spanish brigands were flourishing in all languages except Spanish, Spain's public considered these stories a shame to the nation and a crucial reason for increasing financial support of the Civil Guard (guardia civil). ${ }^{\mathrm{x} i \mathrm{i}}$

While adopting effective measures for securing travelers on Andalucian roads, the government, however, did not show any awareness of the power of the image, naively supposing that the objective changes would automatically make the brigand tales obsolete. Image-making was not as we understand it today, and travelers were left to interpret Spain as they pleased. So, the myth of Spain as a nation of femmes fatales and bandoleros continued to flourish. Yet though the appreciation of the bandit might have remained mostly outside of Spain in the nineteenth century, the debates about the meaning of the bandolero figure were waged inside, and not outside, the country. As recent work shows, the brigands were a social reality with a long-lasting literary impact. In the middle of the nineteenth century, they stepped out of the pages of foreign travelogues and Spanish romantic fiction to become prominent on the Madrid stage and, eventually, to reach the reading public in the provinces through serial novels. ${ }^{x x i i n}$ these literary and theatrical

Journal of Tourism History, Vol 6, No. 1 (2014): pg. 38-56. DOI. This article is @ Taylor \& Francis (Routledge) and permission has been granted for this version to appear in e-Publications@Marquette. Taylor \& Francis (Routledge) does not grant permission for this article to be further copied/distributed or hosted elsewhere without the express permission from Taylor \& Francis (Routledge). 
incarnations, the bandoleros characters initially acted as heroes channeling upper-class anti-absolutist values. Yet as the century progressed, they took on an array of ideological overtones documenting 'uncertainty over legitimate government, and its relationship with a sense (or rather senses) of national identity'. xxiii By the beginning of the twentieth century, brigands were, therefore, a domestic product that responded to, or clashed with, the heritage whose construction was underway on the national scale. Importantly for the ensuing argument, their imaginary faces, attire, and habits were already well engrained into the imagination of Spanish elites.

In the 1900s, institutions responsible for tourism emerged in most European countries, with Spain taking the lead in 1905. Championed by the reformist prime-minister, the Count of Romanones, the National Commission for the Development of Artistic and Leisure Excursions of the Foreign Public embodied the modernizing program of the country's revival from within, beginning with Spain's vast and underdeveloped rural areas. ${ }^{x x i v}$ In light of this agenda, tourism was conceptualized as a modern industry dealing just as much in comfort and security as in art and climate. There was no place for brigands in this picture. So, while foreign correspondents covered with gusto the crimes committed in Andalucía by the armed robber El Vivillo and his band (1904), ${ }^{x \times v}$ the unamused tourism enthusiasts called the actions of Spanish bandoleros a 'dishonor to the country, its culture, and its civility'. xxvi These actions, it was claimed, could not possibly generate the type of tourism that the country needed: while nations such as Switzerland, Italy, or France managed to attract enough foreigners to ensure prosperity for its governments and its people, Spain was scaring its visitors away. An editorial in the liberal daily El Heraldo de Madrid, eloquently titled 'Banditry and schools', had no kind words to spare for the romantic robber:

The love of art stops in the face of a threat of inevitable moral and physical discomfort; if a long stay implies any danger, one is no longer attracted to excellent climate and runs away. Foreigners feel charmed by our country, its every corner, exactly like Spaniards in Maghreb, but they are afraid of our customs, afraid of homo alpinus that seems to inhabit these lands. $x \times v i i$ 
The author's solution? Eradicate Andalusian brigandry by ripping it up by its root: improve the schools in the areas with highest rates of illiteracy since these areas produced most bandits. Spain's days as a titillating destination seemed to be numbered. As for El Vivillo, he emigrated to Argentina, where he was eventually denounced to the police, yet was completely exonerated and greeted back home as a hero. Reportedly, while El Vivillo was still in a Buenos Aires prison, an unknown German gentleman requested from the President of the Argentinean Republic the right to visit EI Vivillo in prison. When asked why, the German replied that he needed to see a real 'bandolero'. ${ }^{x}$ viii The Spanish brigands clearly sold well, even on foreign soil.

\section{A quest for a modern picturesque}

In Helen Carr's relevant rendering, the fad of seeking the 'picturesque' aspects of countries such as Spain was underpinned by the 'anxieties, uncertainties, and increasing dissent' that modernization was causing in the travelers' countries of origin. Thus, intellectually, the nineteenth-century flow of exotic images of Spain had been fueled by 'the profound doubts about the continuation of Western progress, indeed doubts about the possibility of progress at all'.xix Yet having embarked on the tourism project, Spanish state officials construed 'tourism' as synonymous to progress. It seemed like a good time to abolish the Spanish picturesque. Or did it?

Class warfare was steadily on the rise, and armed group robberies went on, still centered in Andalucía. These were, of course, not your romantic bandoleros-their gangs often included members of anarchist parties-yet journalists insisted on using the anachronistic term for them. Soon the bandoleros' ranks grew even bigger, as the heroes of the Mexican revolution, the fighters for national independence in China, and, closer to home, the Moroccan rebels against Spain were also receiving this old and typically-Spanish name. ${ }^{\mathrm{xx}}$ Inside Spain, political instability ushered in the first dictatorship, Miguel Primo de Rivera's Italian-style 'directory' in support of the weakened monarchy of Alfonso XIII (1923-1930). The creation and dissolution of state bodies responsible for tourism accompanied these government changes. In 1911, the National

Journal of Tourism History, Vol 6, No. 1 (2014): pg. 38-56. DOI. This article is @ Taylor \& Francis (Routledge) and permission has been granted for this version to appear in e-Publications@Marquette. Taylor \& Francis (Routledge) does not grant permission for this article to be further copied/distributed or hosted elsewhere without the express permission from Taylor \& Francis (Routledge). 
Commission became the Royal Commissariat for Tourism and Popular Artistic Culture (1911-1928), replaced in 1928 by a new corporate body: the Patronage Board for Tourism. With modifications, this institution survived through the Republic (1931-1939) and the Civil War (1936-1939).

During this time, tourism was so new that the enthusiasts, including the ones working for the government, were still trying to understand how it operated. Some cited the example of Switzerland, where the numbers of visitors increased in direct proportion to the number of modern hotels. Others had their doubts. 'One does not go to Spain as one goes to Switzerland', commented Enrique Gómez Carrillo, a cosmopolitan Nicaraguan intellectual:

Pilgrims from behind the mountains laugh at everything that in Madrid, Seville, Granada, and Toledo can be modern life, modern luxury, modern activity. Of course, they ask for a minimum of comfort and avoid the classic lice, classic putrid oil, and classic wood stove. This is all. As for electrical elevators, electrical dining-rooms, electrical bathrooms, and electrical foods, they profess no enthusiasm for them in Spain. If this were what they wanted, they would go to the United States. ${ }^{x \times x i}$

When the Royal Commissariat for Tourism was created in 1911, its leader, the museum enthusiast Marquis de la Vega Inclán, understood that the wealthy and the well-educated European and Latin-American travelers were Spain's most promising clientele and began to put Spain forward as an 'open-air museum'. ${ }^{x \times x i i}$ Still, as a liberal reformer, the Royal Commissar also considered tourism a way to improve urban hygiene and the social conditions of the laboring classes. Hence, a theory began to emerge that those interested in developing modern-day tourism had to find ways to reinvent the picturesque for new uses. Art and artisanry, many concluded, had the capacity of bridging the gap between the picturesque and the modern, 'because a traveler who crosses the Pyrenees always-always, always, always-is concerned with art, history, and archaeology'. ${ }^{x \times x i i i}$ The uncertainties about how to fix Spain's backward reputation translated into an innovative way of thinking about how to incorporate the backwardness into its modern appeal as a destination.

One proposal came from San Sebastián, Spain's earliest and most modern beach resort. Precisely because tourism in San Sebastián

Journal of Tourism History, Vol 6, No. 1 (2014): pg. 38-56. DOI. This article is (C) Taylor \& Francis (Routledge) and permission has been granted for this version to appear in e-Publications@Marquette. Taylor \& Francis (Routledge) does not grant permission for this article to be further copied/distributed or hosted elsewhere without the express permission from Taylor \& Francis (Routledge). 
had always eschewed any association with unsafe, colorful places like Seville, in 1923 its residents were appalled by an article in the French Vogue whose author depicted the city as a Romantic resort delivering every Spanish stereotype, from the bandoleros to naughty marquises. When the inhabitants complained, Emilio Pisón-the journalist, poet, and a prominent member of the local Athenaeum-suggested they learn instead about the 'value of the picturesque' and begin to 'exploit this rich inexhaustible mine'. ${ }^{x x i v}$ Cosmopolitan tourists, he stated, wanted 'to see the picturesque, the typical, the deep (racial), that which does not exist in their countries'. And so, in Pisón's rendering, having found in San Sebastián a beach 'like all other beaches, like Trouville, like Dauville, like Ostende' the author of the Vogue decided to 'cover the naked truth with a transparent veil of fantasy'. One should not assume, however, that Pisón was proposing that San Sebastián re-import Carmen and Don José, who were, after all, Basque originals. Rather, his notion of taming the picturesque consisted in learning how to stage it. The following paragraph explains the modern picturesque better than many heritage planners of our times:

The French, who understand business, care most diligently for the primary detail of grand tourism. Without stopping to organize other types of celebrations-Hippodrome, concerts, 'souper-dansants'-they never forget the picturesque note. They know that here lies the secret of attracting foreigners. And so, if the picturesque note could be higher, more suggestive, more vibrant, they do not hesitate to falsify it.

Because the real charm of the picturesque lies precisely in mixing it a little bit with other things. One has to sharpen the colors to avoid appearing too banal. One has to insert the picturesque like a virtuoso, with something of a 'cabotinage'.... Foreigners have a slightly exaggerated vision of things. Show them reality, and they will feel deceived. It is better to augment it, falsify it discretely, and this way it will be more credible.... ${ }^{x \times x}$

Crucially, Pisón's remarkably modern insistence on the importance of the verisimilitude effect for tourism had an old foundation: the nineteenth-century notion of the typical as an artifice grounded in the mastery of a recognizable detail. Even the quote about fantasy that he used came from the Portuguese writer José María Eça de Queiroz, a nineteenth-century realist. The concept of modern picturesque was 
therefore developed in accordance with nineteenth-century aesthetics, as an artifice or, in Pisón's own words, as a "mise-en-scène' of the picturesque'.xxxvi The idea that backwardness could be reframed as a spin on the modern, agreed with the reformist elites' belief that oldstyle local customs and artifacts could be incorporated into modern lifestyles with the purpose of humanizing them.

\section{Bandits as heritage}

This is how the bandoleros, an inherent part of Spain's old picturesque, became relevant-not as a real social threat, but as a part of the landscape or, as Hipólito Finat (II Marquis de Carvajal) wrote, as 'a magnificent and free advertisement to the Spanish economy'. xxxvii Faithful to the spirit of his times, the author imagined encounters with bandoleros as a visual experience: a 'beautiful jaw-dropping show' that could spur foreigners' imaginations. xxxviii These improbable images, he concluded, had already become a 'historical truth'. Just like this author, Spain's early tourism enthusiasts were descendants of the nineteenthcentury antimonarchical liberals who had enjoyed the subversive bandoleros plays or 'bandit novels that used to charm our grandfathers', as one anonymous writer described it. xxxix A year later, humorously mourning the capture and assassination of a bandolero named El Garabato, another anonymous writer listed all things dear to any Spaniard that the bandit reminded him of, including the censorship that the first generation of Spanish antimonarchists had fought: 'the red fury of stove-shovel in the fire, the hungry prose of serial novels that spread the bandit's fame, and even the mark of the red pencil which in a second does away with what we thought to be our most sacred freedoms'. ${ }^{x}$ The tradition of bandit fiction and theater was making many pundits aware of all the things that the bandoleros images could do for different audiences. Hence, while it seemed clear that bandits should be eliminated, some were wondering if they could also find other uses for them.

This was a complex and contradictory position that eventually produced a radical split between brigandry as a part of Andalusian heritage and the actual armed anarchist-led struggle that continued in Andalucía. Such was, in fact, the conclusion made by Constancio 
Bernaldo de Quirós, the pioneer of Spanish criminology (1873-1959) dispatched by the government's Science Agency (Junta de Ampliación de Estudios e Investigaciones Científicas) to study the revolts in Andalucía. In a report published in 1912 and many times re-edited, he argued that there was 'no special connection between the two phenomena: banditry (bandolerismo) and subversive delinquency'. ${ }^{\text {li }}$ At a time when rural anarchists were employing the bandit tactics, Quirós's real concern as a criminal anthropologist working for the Institute of Social Reforms was to understand whether the roots of anarchism in Andalucía were as deep as the ones that bandits were assumed to have. His study demonstrated that anarchism was a much newer phenomenon in the region than the banditry with which it was often confused. In the following years, Quirós would focus on othersocio-economic-sources of the revolts, such as the atavistic system of land ownership among Andalusian peasants, the problem that he would subsequently attempt to eradicate as a member of the commission that drafted the Second Republic's project of Agrarian reform (1931). xlii As for the bandits, these, he claimed, were no more than exaggerated representatives of the Andalusian race taking one of two equally harmless forms: those who, 'without any inner drama, without conflicts of critical social adversity, run to the fields following a vocation, turning it into a profession', and others, who never harm their compatriots, focusing exclusively on 'strangers, or, speaking more clearly, people from other places (forasteros)'. xliii Brigands, Quirós concluded, were a 'purely ethnographic'xliv phenomenon that had nothing to do with anarchism. After that, it would not take much before they were protected as local heritage.

Indeed, this is what several Spanish writers asked the government to do in the following years, albeit in a humorous way: help revive this dying profession that could serve the needs of national tourism so well. For example, in 1920, when a new band of bandits gathered in the vicinities of Málaga, one humorist put the Royal Commissariat's concern for refashioning Spain as a museum to a good use. Wherever bandits are out, tourists would follow, he stated, and Spaniards should therefore do their best to 'study' banditry, if not as a form of fine art, as Thomas de Quincy would say, at least as a useful activity. This was, however, an anti-government joke because, in the author's own words, tourism was only needed 'to help us fund the excesses with which Spain's state has adorned its bureaucratic set-

Journal of Tourism History, Vol 6, No. 1 (2014): pg. 38-56. DOI. This article is (C) Taylor \& Francis (Routledge) and permission has been granted for this version to appear in e-Publications@ Marquette. Taylor \& Francis (Routledge) does not grant permission for this article to be further copied/distributed or hosted elsewhere without the express permission from Taylor \& Francis (Routledge). 
ups'. ${ }^{x \mid v}$ Sarcastically connecting banditry and the interest in tourism coming from the social reformists in the government, the writer suggested that instead of fighting bandits, the police should protect their 'honorable and legal trafficking' and encourage them to relocate their work, their display of 'heroic spirit' and their 'sacrifice for the Fatherland' to the cites, making it unnecessary for them to hide in rural areas: 'please note that we are not joking: deploying some bands of these authentic bandoleros on the rabbit trails of the Andalusian mountains would allow our nation to recover the prestige that it has lost among the clients of the Cook Agency'.xlvi

In 1925, during the dictatorship, the satiric weekly Muchas Gracias ran similar coverage, by Mariano Tomás, of a new band that had appeared in the mountains of Sierra Morena: 'Since gentleman Pernales found an end worthy of his fair fame, back in our beloved mountains of Alcaraz, we were in despair and would not bet a cent on our country's good name. We were still managing to support, with a lot of effort, several dozen bullfighters and a rare smuggler. But in bandits we were lacking; we were missing even a half-decent one'.xlvii Just like the previous author, Tomás used the popularity of the bandit image and applied it to real armed activity that, in his words, seemed to exude 'a putrid odor of a Spanish show (españolada)'. xlviii The real problem was no longer the bandits themselves, the author claimed, but rather their poor preparedness for the profession. The true masters of the bandoleros business had all died, leaving their heirs with the roles of poor imitators-or with enough bandit books to support a 'doctoral program':

We have to content ourselves with the aficionado gentlemen who run into the fields without study or schooling; but we have to take care of them, so that they will not disappear. And although the numbers are small and their knowledge of the profession is rudimentary, we have to advertise them abroad as worthy successors of the (historical band) Seven Youths from Écija. Tourism would increase and maybe our country would receive the place that it deserves in the Society of Nations. ${ }^{x i x}$

In both texts, the underlying motif was that, by reinventing a modern bandolero, tourism could somehow assist in reducing a social problem to an 'ethnic art' of sorts.'

Journal of Tourism History, Vol 6, No. 1 (2014): pg. 38-56. DOI. This article is @ Taylor \& Francis (Routledge) and permission has been granted for this version to appear in e-Publications@Marquette. Taylor \& Francis (Routledge) does not grant permission for this article to be further copied/distributed or hosted elsewhere without the express permission from Taylor \& Francis (Routledge). 
Such humorous takes on contemporary crime indicated that by the 1920 s the readers of popular press already recognized bandits, not only as real criminals, but also as an exportable part of Spain's image. In the spirit of their times, authors, furthermore, used humor to explore the possibilities of cross-class and rural-urban solidarity. The professional and urban bandits that they imagined in Spain's prosperous future served as a convenient image to imagine how such solidarity would also contribute to Spain's economy and international prestige.

However, not all references to the 'heritage' bandits were humorous. Government officials, too, conjured the image when it was necessary to address real crime. In 1927, when the London Times reported that two Englishmen travelling in a car in Northern Spain were robbed and murdered on a Spanish road, li Spanish ambassador, Merry del Val, wrote an energetic rebuttal: 'There are no bandits in Spain'.lii Instead of expressing his sympathy to the victims, the ambassador brandished his literary knowledge, making it seem that brigands only existed in fiction: 'Banditry has been suppressed in Spain for many a long year, and to speak of bandits in the North of Spain is to raise a smile on the lips of all Spaniards who remember Théophile Gautier's famous 'howler', when he placed the scene of an imaginary act of brigandage in the pass of Pancorbo, near Burgos, where no such crime has ever been known'. In this account, bandits were either a fiction or a thing from Andalucía (or both), and travelers in Northern Spain had nothing to fear: the real criminals had no interest in harming tourists, nor could they be classified as 'bandits'.

In 1928, when Vega Inclán's Royal Commissariat was replaced by the National Patronage Board with the explicit purpose of putting Spain forward as a stable, safe, and modern destination, liii heritage bandits temporarily lost currency. While Primo de Rivera was in power, the Patronage Board developed a whole array of heritage products ranging from food to climate, yet at the meetings its members never mentioned bandoleros. The press also stopped musing about brigand tourism. Instead, the Correspondencia Militar condemned the brigands' popularity among foreigners and its influence on locals:

This is the Spain they paint in books, in fantasy stories written by travelers who studied her superficially! And though it is painful and brutal to have to confess it, it is also true that even

Journal of Tourism History, Vol 6, No. 1 (2014): pg. 38-56. DOI. This article is @ Taylor \& Francis (Routledge) and permission has been granted for this version to appear in e-Publications@Marquette. Taylor \& Francis (Routledge) does not grant permission for this article to be further copied/distributed or hosted elsewhere without the express permission from Taylor \& Francis (Routledge). 
if the legendary Spanish smuggler, highwayman, and bandolero type no longer exists outside their feverish imaginations, what still remains (be it because of some racial atavism or for any other reason) is the habit of wanting to separate oneself from the State, defrauding its tax code, and violating its laws. .iv $^{2}$

These were sobering words that denounced brigand-loving seekers of social harmony as bad patriots, reminding how deeply the bandoleros myth undermined modern values such as the respect for the state and its institutions.

When King Alfonso XIII fled Spain and the II Republic was proclaimed, the Patronage Board continued its work. In 1933, the Republic's reformist parties lost the election, ushering in a conservative cabinet. Yet strangely, as the conservatives in power were breaking with the image of social harmony that the previous governments had tried to project (in part by recasting peasant rebellions in the south as harmless), the heritage bandits were back. 'National Artistic Treasure', ran the title of an article on bandoleros in a satirical newspaper Gutiérrrez. The subtitle explained: 'As Pasos Largos has passed away, we Spaniards only have for a bandit the nephew of Flores Arrocha, and he is a fluke. The Patronage board will have to decide what to do'. ${ }^{\text {Iv }}$ In the rest of the article, the author proposed that the Patronage board 'encourage folks' by organizing competitions, announcing a 'bandoleros Nobel prize', and conceding government pensions to those wishing to dedicate themselves to this profession: 'such is the mandate of our long history'. Ivi Spain's changing governments and political regimes did not seem to affect the image of touristy bandits that allowed writers to say 'we, the Spaniards' and imagine a community as if it were not torn apart by class warfare. Such a peaceful use of the bandit figure was, of course, reduced to travesty when General Francisco Franco's supporters, calling themselves 'nationals', won the Civil War (1936-1939) and started to apply the term 'bandoleros' to the remaining soldiers of the Republican army that had retreated to the mountains and continued offering armed resistance. ${ }^{\text {Ivii }}$ 
NOT THE PUBLISHED VERSION; this is the author's final, peer-reviewed manuscript. The published version may be accessed by following the link in the citation at the bottom of the page.

\section{Celluloid bandits.}

It was easy to present a character that had already passed into the realm of imagination as a tourism attraction, rather than a threat. Yet a new question arises. In the twentieth century, as all these debates were taking place on the pages of the Spanish press, a new agent, cinema, was emerging and gradually taking the lead in place promotion. Born as a transnational art form, film relied on foreign markets feeding off universally-recognizable clichés. Iviii Were any brigand films made at that time meant to promote Spanish tourism? The answer is, yes and no: although many films at the time featured brigands as their main or secondary characters, these were not tourism propaganda movies. Rather, the brigand films encapsulated a different type of mobility: the potential of selling the image of Spain remotely, to those who did not travel. More importantly, just like the written images of ethnographic brigands, these films circulated widely and were particularly well received at home, especially among the elites who shared the cosmopolitan vision of Spain as an exotic place or were eager to see the literary debates about the government continue on screen. In short, film made the bandoleros a commodity valuable both for export and import.

First, however: why weren't the bandolero films used to attract tourists to Spain? Although the tourism business was quick to discover the potential of film for promoting places, until the end of the 1920s, the genre of choice were 'vistas' and actuality cinema rather than plotdriven cinematic narratives. For example, even in 1928 when the Patronato del Turismo was created and began to receive petitions for film promotion and projection devices, these only involved views of places. The First Spanish Cinematography Congress, held in Madrid in October 1929 in conjunction with the 1928-1929 Ibero-American and World Fairs, only discussed 'documentary film as a medium by which nations could 'see' each other'. The delegates' sole decision was to 'propagate through film the beauty of our provinces'. lix The result was a series of documentaries showing views of Spain's provincial capitals.

Yet thought about narrative film and its importance to tourism began to emerge already in the early 1920s, when domestic production consolidated as an industry. The balance of the debate was that the origin of images of Spain circulating abroad mattered just as 
much as the content, and this meant that Spanish film producers had to find ways of harnessing stereotypical images of their country. In 1922, a reviewer for the Correspondencia de España who called himself Kar-Lynes credited cinema with a sea-change in Spain's international reputation:

Having chosen our fatherland as its setting, film propagated with photographic precision the reality of our land, our costume, and our customs, and the tragic Spain of Merimée and the no less novelistic one by $\mathrm{E}$. de Amicis got transformed into the real vision of Spain as we understand it, without ridiculous exaggerations that made us smile at our own portraits in operas and books by foreign writers. ${ }^{1 \mathrm{x}}$

Portraying 'reality', however, did not imply that the local color had to be erased from film-that would make films unsellable. In fact, the reviewer above was praising the film La reina mora, dedicated to 'Andalusian customs', which included considerable amounts of dancing and singing. Filmed versions of musical operas, zarzuelas, widely popular at home but rarely known abroad, dominated Spain's early film production even before the talkies. La reina mora was one of such films that encapsulated the essence of the early debates about local imagery on film. Engaging the well-developed domestic markets yet also taking advantage of the movies' international circulation, Spanish film directors were encouraged to project Spanish versions of Spanish life, and distributors were encouraged to deliver these products to the public.

Movies were a product made to be sold, and while the answer to the question about what it meant to sell a destination was in flux, film directors were learning how to sell illusions. The bandoleros characters fit the bill because they were highly exportable, yet also domestically popular. Although, since film production was centered in Barcelona, Valencia, and later Madrid, films involving bandits emerged as a product that was either transregional or transnational, or both, because they featured characters from Andalucía. The only exception was the first Spanish film brigand: the Catalan aristocrat Don Joan Sala i Serrallonga. In 1910, Alberto Baños and Ricardo de Marros working for Hispano Films in Barcelona produced the first version of Don Juan de Serrallonga, starring Cecilio Rodríguez de la Vega and María Dolores Puchol, and photographed by Ramón de Baños. This first bandoleros project, based on the mid-nineteenth century novel by 
Catalan revivalist Víctor Balaguer, capitalized on the early-century regionalist spirit while also taking advantage of the international popularity of Andalusian bandoleros. Marking the dawn of the film industry in Spain, this was the first production of Baños' and Marros' Hispano Films, a commercial studio that they opened in 1909 in Barcelona, seeking to acquire peninsular as well as Latin American distribution. So, instead of betting on Catalonian heroes only, Baños and Marros soon began to exploit the local color of other regions by producing films such as Carmen, or: A smuggler's daughter (Carmen o la hija del contrabandista) and Gypsy jealousy (Celos gitanos) in 1911, Andalusian love (Amor andaluz) and A Drama in Aragón (Un drama en Aragón) in 1913, and Diego Corrientes (dir. Alberto Marro) in 1914.

After Hispano Films' 1910 prototype, a genre began to develop. In 1911, a film by Valencian director H.B. Cuesta titled The Bandits of Sierra Morena [Los bandidos de Sierra Morena] (1911) (Fig. 1) told a story of the so-called 'Seven Youths from Ecija [Los nueve niños de Écija]'. Ixi In 1912, Segundo de Chomón, a Spaniard who worked all around Europe, filmed a bandit film Andalusian Superstition, produced by Iberian Film, a Spanish wing of the French Pathé Studios headquartered in Barcelona. These silent films used the conventions of early American Westerns to deliver narratives set in Spain that capitalized on the popularity of written and theatrical bandits. Contemporary with the Royal Commissariat's program of promoting Spain as a vast museum and the debates about the picturesque, these films offered sublime vistas of Andalucian mountains (real and simulated in the studio setting) alongside fascinating spectacles that only the new media could create. Chomón's film, for example, featured an uncanny image of a bandits' cave equipped with cupboards full of animated scientific specimen. That was the year when Quirós coined the term 'ethnographic' bandolero, and images such as these were making the bandits both folkloric and modern, in accordance with the new picturesque aesthetics.

\section{INSERT FIGURE 1 NEAR HERE}

If the first filmed brigands hailed from the regions, Primo de Rivera's efforts to create a competitive centralized nation did not leave film production untouched. Relocating the national imagery that had hitherto come from the Mediterranean and launching it internationally became the agenda of the Madrid studios. Following the 1922 
marketing miracle of Hollywood's Blood and Sand (based on an eponymous 1808 novel by Blasco Ibáñez), bullfight plots became all the rage, and the Madrid studios were poised to recapture the monopoly. The bandoleros characters acquired new importance because they had plots of their own while also fitting well into secondary plot lines. For example, in 1924, the Madrid studio Films Española produced a new version of the life of Diego Corrientes (José Buchs, 1924). The next year, Buchs's La hija del corregidor (dir. José Buchs, starring José García 'Algabeño') (Figs. 2 and 3) featured a subplot involving José María el Tempranillo. Ixii

\section{INSERT FIGURES 2 AND 3 NEAR HERE}

The same time period saw the rise of another brigand character, Luis Candelas. Unlike his counterparts, Candelas was not a rustic character from periphery, but rather a defender of the poor and a fighter against the rich residing in Spain's capital, Madrid. In 1925 José Buchs filmed La extraña aventura de Luis Candelas as part of his folkloric series, and the next year, Armand Guerralxiii followed suit with his own Luis Candelas, el bandido de Madrid (1926), scripted by Tomás Álvarez Angulo. The latter film created a centralized myth of its own, with Luis Candelas, unlike his well-studied real prototype, dressed as a rider from the Andalusian countryside yet disappearing into the mountains near Madrid at the end of the movie. Apparently, by the mid 1920s, the conventions of how a bandolero should look and behave had become clear. These images turned out to be so lasting that even contemporary tourist can see them reincarnated in the Calabria hats and the Trabucos hanging across the waiters' chests in the popular Madrid tavern, The Cave of Luis Candelas in the wall of the Plaza Mayor.

With the creation of the Luis Candelas sequence, the task of bringing the bandoleros narratives to Madrid was achieved. The arrival of the talkies at the end of the decade marked a further step: bandits 'made in Spain' stepped out to the international market. With the interest in winning Latin American audiences on the rise, Hollywood producers needed plots that would easily lend themselves to these new audiences, and the bandoleros, identifiable as any armed criminals in any country, became hot currency. Hollywood studios contracted Spanish actors such as Antonio Moreno to recast them as international bandoleros-for example, the Mexican Pancho Villa 
(Pancho López in the film El hombre malo [1930]). Ixiv Mexican opera singer José Mojica, on the other hand, starred (alongside Moreno) in the Spanish-based plot One Mad Kiss (1930), Fox's first film shot directly in Spanish, and it became an instant box office success. ${ }^{1 \times v}$ Spain's transatlantic ties were also strong enough to support coproductions, cutting out the Hollywood middlemen. For example, in as early as 1928, Mexican director Miguel Contreras Torres traveled to Madrid to shoot a bandoleros story for the Mexican market: El leon de Sierra Morena. ${ }^{\mid x v i}$

These examples suggest that by the end of 1920 s the bandoleros characters attracted the attention of both Spanish and foreign film directors. At a time when pundits were forging the image of a heritage bandit, supporters of Spain's tourism industry and film directors were exploring ways to sell bandits outside of Spain. It would be logical to suppose that those responsible for Spanish tourism business would put the burgeoning interests in bandit film to use as tourism advertisement. Still, the idea that narrative cinema could be tourism promotion did not cross tourism officials' minds until 1929. It was Luis Antonio Bolín, then a forward-thinking representative of Andalucía in the Patronage Boards for Tourism (and during the Civil War, the creator of the first tours of Franco's battlefields), who, during the discussions of the 1930 budget, defended the potential of fictional plots in the promotion of tourism. In an unprecedented move, he proposed the Patronato to co-produce a movie with one of the big film studios (presumably, a Hollywood one):

This is a genre of propaganda for which we would have to secure the collaboration of a grand company that would supply its own professionals and artists, although it might work under a Spanish director. During 1930, the Patronage Board would test this extremely effective propaganda instrument by means of a carefully-studied film. It is possible that the money invested could be returned with interest. The budget could be 600 000. Ixvii

We do not know whether this film was ever made. At the end of January of 1930, the dictator Primo de Rivera resigned, and the King charged General Dámaso Berenguer with forming a new government. Soon after, the Patronage Board failed an audit and had to restructure. ${ }^{\mid x v i i i}$ It no longer had the funding to produce movies. In June of 1936, the president of the Patronage Board under the II Republic's Popular Front Government that had won the election in

Journal of Tourism History, Vol 6, No. 1 (2014): pg. 38-56. DOI. This article is (C) Taylor \& Francis (Routledge) and permission has been granted for this version to appear in e-Publications@Marquette. Taylor \& Francis (Routledge) does not grant permission for this article to be further copied/distributed or hosted elsewhere without the express permission from Taylor \& Francis (Routledge). 
early 1936, received a letter from the Amateur Film Association of Madrid that spoke eloquently about the need to create something to oppose the 'sticky and redundant exoticism' with which commercial cinema (foreign and domestic) was 'saturating' the market. ${ }^{\mid x i x}$ The alternative was, the writer stated, 'amateur cinema, free from any financial interest'. ${ }^{1 \times x}$ From this perspective, all promoters of the modern picturesque were equal in their complacency with the outdated views of Spain, and only a revolutionary move could offer a solution. In a few weeks, a military coup broke out, followed by the Civil War, and the questions about the projection of Spain's image acquired much more morbid importance.

\section{Conclusions}

Image packaging and export are usually approached as postmodern concerns belonging to the era of the heritage industry. The theory of 'heritagization' of place-bound legends and myths as a means of generating tourism-related income (as coined by Robert Hewison)-also emerged as a response to the post-1970s surge in heritage tourism. ${ }^{\text {Ixi }}$ Still, 'ethnographic' bandits circulated on film, in daily press, and social research long before private foundations and authorities began to offer them as tourist attractions. This article argues for extending the timeline of heritage to the early 1900s, when European elites understood that the reputation of their domestic landscapes, customs, and artifacts was acquiring currency on the emerging tourism market.

The place-images that emerged from their debates piggybacked on the fame of characters that had already gained transnational popularity while also exploring ways of modernizing these characters through staging or simulation. Yet in the absence of real bandit-driven tourism, early heritage such as the brigands worked the best on film and at home. Film directors rejoiced in their rich visual world, creating prototypes so lasting that even modern restaurant owners find it worthy of being reproduced. At a time of anarchist revolts and military coups that limited the freedom of press, many people had reason to discuss bandits, seeing them as a safe alternative to debating class struggle. Some writers and politicians interested in maintaining the illusion of social peace and interclass harmony were eager to discuss the tourism potential of the 'heritage' bandolero as a substitute for a rebellious peasant. Others, associating the brigands with the permission has been granted for this version to appear in e-Publications@Marquette. Taylor \& Francis (Routledge) does not grant permission for this article to be further copied/distributed or hosted elsewhere without the express permission from Taylor \& Francis (Routledge). 
nineteenth-century debates about self-government, liked the characters' nostalgic overtones. And quite a few seemed to agree about their usefulness as a tourism illusion. In other words, even though there were no theme parks or woods dedicated to bandits, the bandit heritage enjoyed both popular and governmental support, and there were many (sometimes divergent) reasons for keeping the idea of bandolero alive.

Yet questions remain. The first decades of the twentieth century are known as a time of competing notions of regionalism and centralism, yet the debates about the Andalusian 'ethnographic' bandits were mostly waged on the pages of the central press, and no bandolero film has ever been produced in Andalucía. Whom did the bandit heritage really represent? From Quirós's criminal anthropology to the Hollywood factory of illusions, the twentieth-century discourse about the bandoleros was rooted in the reification of national culture through its lower-class and regional markers. As the elites thus collaborated with foreigners in the production of a modern, marketable, identifiable identity, the Andalusians themselves, let alone the real armed gangs, were excluded from this process. This conclusion opens an intriguing path to the present-day bandit products that import this centralist and 'othered' view and rebrand it as a regional marker. The 'Woods of Witches and Bandits' was inaugurated in 2013, in the midst of a heated debate about Catalan independence from Spain. Whom does this product, co-designed by Spain's central tourism agency and the Andalusian local governments represent? Even further, what kind of Andalucía is the 'Land of José María el Tempranillo'? The genealogy of modern heritage discourses gleans insights that are needed to figure this out.

\section{Notes}

i 'Bandit' and 'brigand', two most common English equivalents of the Spanish word 'bandolero', are used in this article interchangeably. The authors wish to thank Sally Anna Boyle and this journal's anonymous referees for their corrections and suggestions concerning the style and the content of this article. 
ii 'Resolución de 17 de noviembre de 2010, de la Secretaría General de Turismo y Comercio Interior, el Convenio de colaboración entre el Instituto de Turismo de España, la Administración de la Generalitat de Cataluña, la Asociación de Municipios para el Desarrollo del Plan de Competitividad Turística Bosques de Brujas y Bandoleros y la Federación de Empresarios Turísticos Montseny-Guilleries', BOE 302, December 13 (2010) Sec. III, 103383.

iii http://rutadeltempranillo.org/, accessed July 16, 2013.

iv The Jornadas sobre el Bandolerismo en Andalucia were celebrated annually between 1998 and 2006. Currently the Foundation hosts lecture series on the same topic.

$\checkmark$ Stephen Brown, Marketing - The Retro Revolution (London: Sage, 2001), 148-49.

vi Michael Barke and John Towner, 'Exploring the history of leisure and tourism in Spain', in Tourism in Spain: Critical issues, ed. Michael Barke et al. (Wallingford, CT: CAB International, 1996), 3-34.

vii The first, 1726, edition of Diccionario de la lengua castellana, en que se explica el verdadero sentido de las cosas [...], a.k.a. Diccionario de autoridades de la Real Academia Española reflected this definition (Madrid: Imprenta de Francisco del Hierro, 1726), v. 1, 545.

viii For more information, see José Santos Torres, El bandolerismo en Andalucía, papeles de ladrones y jueces de bandidos (Brenes (Sevilla): Muñoz Moya y Montravera editores, 1991); Victoria Sau, El catalán. Un bandolero especial (Barcelona: Aura 1973); Florentino Hernández Girbal, Bandidos célebres españoles (Madrid, Ed. Lira: 1976); Joaquín Álvarez Barrientos and Pilar García Mouton, 'Bandoleros y bandidos. Ensayo de interpretación', Revista de dialectología y tradiciones populares, 1986, 7-58; Emilio Soler Pascual, 'El trabuco romántico. Viajeros franceses y bandoleros españoles en la Andalucía del siglo XIX', in: La cultura del otro: español en Fracia, francés en España, ed. Manuel Bruña (Sevilla, Universidad de Sevilla, 2006), 687-99, http://www.culturadelotro.us.es/actasehfi/pdf/ (accessed February 23, 2014); José Antonio Rodríguez Martín, 'Una aproximación al bandolerismo en España', Iberoamericana VIII, 31 (2008), 85-105.

ix Francisco L. Díaz Torejón, Guerrilla, contraguerilla y delincuencia en la Andalucía Napoleónica 1810-12 (Lucena: Fundación Ruta del Tempranillo, 2004); Gutmaro Gómez Bravo, 'El paisaje de la violencia', Cuadernos de Historia Contemporánea, no 24 (2004), 161-80.

× Gatherings from Spain (London: Murray, 1846), 186.

xi The authors are grateful to Rachel Koroloff for this last remark. In another version of the story, a group of Dumas's aristocratic admirers in Seville simply staged a robbery to please the writer (Eduardo Zamacois, 'Ladrones para turistas', El Imparcial Nov 11, 1928, 6).

Journal of Tourism History, Vol 6, No. 1 (2014): pg. 38-56. DOI. This article is @ Taylor \& Francis (Routledge) and permission has been granted for this version to appear in e-Publications@Marquette. Taylor \& Francis (Routledge) does not grant permission for this article to be further copied/distributed or hosted elsewhere without the express permission from Taylor \& Francis (Routledge). 
xii Diccionario de la Lengua española, ed. José Alemany y Bolufer (Barcelona: Ramón Sopena, 1917), 221.

xiii Real Academia Española, Diccionario histórico de la lengua española (Madrid, 1936, v. II), 75.

xiv The images that Spain's early tourism authorities were seeking to project are described in detail in María Rosa Cal Martínez, 'La propaganda del turismo en España. Primeras organizaciones', Historia y comunicación social 2 (1997): 125-33; Juan Carlos González Morales, 'Turismo en España (1905-1931)', Doctoral Dissertation (Getafe: Universidad Carlos III, Departamento de Humanidades, Comunicación y Documentación, 2003, unpublished); Ana Moreno Garrido, Turismo y Nación: La definición de la identidad nacional a través de los símbolos turísticos (España 1908-1929), Doctoral Dissertation (Madrid: Universidad Complutense: 2005; unpublished); Sasha D. Pack, Tourism and Dictatorship: Europe's Peaceful Invasion of Franco's Spain (New York and Houndmills: Palgrave Macmillan, 2006); Ana Moreno Garrido, Historia del turismo en España en el siglo XX (Madrid: Síntesis, 2007); Rosa Cal Martínez and Beatriz Correyero Ruiz, Turismo, la mayor propaganda de Estado (Madrid: Visión Net, 2008); Sasha D. Pack, 'Tourism, Modernization, and Difference: A Twentieth-Century Spanish Paradigm', Sport in Society 11 (6) (2008): 657-72, and 'Revival of the Pilgrimage to Santiago de Compostela: The Politics of Religious, National, and European Patrimony, 1879-1988', The Journal of Modern History 82: 2 (June 2010), 335-367, Eric Storm, 'Una España más española. La influencia del turismo en la imagen nacional', in Ser españoles. Imaginarios nacionalistas en el siglo XX, ed. Javier Moreno Luzón and Xosé Manoel Núñez Seixas (Barcelona: RBA, 2013) 529-59, and Eugenia Afinoguénova, 'An Organic Nation: State-Run Tourism, Regionalism, and Food in Spain, 1905-1931', The Journal of Modern History, forthcoming 2014.

${ }^{x v}$ Gregory John Ashworth, 'From history to heritage-from heritage to identity. In search of concepts and models', in Building a New Heritage. Tourism, Culture and Identity in the New Europe, ed. G. J. Ashworth and P. J. Larkham (London: Routledge, 1994), 13-30; Laurajane Smith, Uses of Heritage (London: Routledge, 2006), 11.

xvi Comparable approaches to heritage as a debate, rather than a product, can be found in Rudy Koshar's analysis the early German preservationist movement (Germany's Transient Pasts: Preservation and National Memory in the Twentieth Century [Chapel Hill, University of North Carolina Press, 1998]) and, closer to Spain, in Carolyn Boyd's examination of the discussions that surrounded the codification of the shrine of Covadonga as a national monument ('The Second Battle of Covadonga: The Politics of Commemoration in Modern Spain', History

Journal of Tourism History, Vol 6, No. 1 (2014): pg. 38-56. DOI. This article is (C) Taylor \& Francis (Routledge) and permission has been granted for this version to appear in e-Publications@Marquette. Taylor \& Francis (Routledge) does not grant permission for this article to be further copied/distributed or hosted elsewhere without the express permission from Taylor \& Francis (Routledge). 
and Memory 14, 1/2 (2002): 37-64). The journal Hispania. Revista española de historia has recently dedicated an issue to what can be called a pre-history of heritage in the context of the early-century 'regenerationist' movement in Spain: Imaginarios nacionalistas españoles en el primer tercio del siglo XX, Hispania 73: 244 (2013), guest-edited by Javier Moreno Luzón. See, especially, Moreno Luzón, 'Alfonso "el Regenerador". Monarquía escénica e imaginario nacionalista español, en perspectiva comparada (1902-1913)', 319-48, 'Patrimonio local, turismo e identidad nacional en una ciudad de provincias: Toledo a principios del siglo XX', 349-77, and Jacobo García Álvarez, 'Paisaje, memoria histórica e identidad nacional en los inicios de la política de conservación de la naturaleza en España: de Covadonga a San Juan de la Peña', 409-38.

xvii John Urry, The Tourist Gaze, 2nd ed. (London, 2002) and 'The 'consuming' of place', in Discourse, Communication, and Tourism, ed. Adam Jaworski and Annette Pritchard (Clevedon: Channel View Publications, 2005), 1927.

xviii José F. Colmeiro, 'Exorcising exoticism: Carmen and the construction of Oriental Spain', Comparative Literature, 54 (2002), 127-44.

xix Relevant for understanding the Spanish banditry are Eric Hobsbawm's Primitive Rebels: Studies in Archaic Forms of Social Movement in the 19th and 20th Centuries (Manchester: Manchester University Press, 1959) and Bandits (London: Liedenfeld and Nicholson, 1969; revised edition New York: Pantheon, 1981) and the subsequent debates in Anton Blok, 'The Peasant and the Brigand: Social Banditry Reconsidered', Comparative Studies in Society and History, 14 (1972), 494-503, followed by Hobsbawm's response, 503-505), Pat O'Malley, 'Social bandits, modern capitalism and the traditional peasantry: A critique of Hobsbawm', The Journal of Peasant Studies 6 (1979), 489501, and Kim Wagner, 'Thuggee and Social Banditry Reconsidered', Historical Journal, 50 (2007) 353-76.

$x x$ Timothy Mitchell, Passional Culture: Emotion, Religion and Society in Southern Spain (University of Pennsylvania Press, 1990), quoted in Ben Dodds, 'Representations of bandits in mid-nineteenth-century Spain', Cultural and Social History, 9: 2 (2012), 207-25.

xxi Dodds, 219.

xxii Manuel Moreno Alonso, 'La invención del bandolerismo romántico', in El bandolerismo en Andalucía. IV Jornadas sobre el bandolerismo en Andalucía (Lucena: Fundación Tierras de José María el Tempranillo, 2001), 59-102; Dodds 2012.

xxiii Dodds, 208.

Journal of Tourism History, Vol 6, No. 1 (2014): pg. 38-56. DOI. This article is @ Taylor \& Francis (Routledge) and permission has been granted for this version to appear in e-Publications@Marquette. Taylor \& Francis (Routledge) does not grant permission for this article to be further copied/distributed or hosted elsewhere without the express permission from Taylor \& Francis (Routledge). 
xxiv Eugenia Afinoguénova, 'An Organic Nation: State-Run Tourism, Regionalism, and Food in Spain, 1905-1931', The Journal of Modern History, forthcoming December 2014.

xxv Scripps-McRae Cablegram, 'Bandits in Spain Madrid, March 12, 1904 - Five highway-men hoarded the Andalusian express near Granada last night and held up the passengers. A considerable amount of money and jewelry was obtained'.

xxvi Anonymous, 'Los bandoleros y las escuelas', El Heraldo de Madrid, Sept. 26 $1905,1$.

xxvii Ibid.

xxviii José Mondego, 'El Vivillo, dashing bandit now a prisoner, was idolized by Spanish women', Milwaukee Sentinel, May 101908.

xxix Helen Carr, 'Modernism and Travel (1880-1940)', in The Cambridge Companion to Travel Writing, ed. Peter Hulme and Tim Youngs (Cambridge: Cambridge University Press, 2002), 73.

xxx Additionally, the term was applied to armed criminal activity around the globe, especially and with noticeable gusto to describing criminals in countries such as Great Britain, France, Switzerland, and the United States.

xxxi Enrique Gómez Carrillo, 'Lo del turismo', El Liberal, October 28 1913, 2.

xxxii Eugenia Afinoguénova, 'El discurso del turismo y la configuración de una identidad nacional para España', in Cine, imaginario, turismo: Estrategias de seducción, ed. Antonia del Rey Reguillo (Valencia: Tirant le Blanc, 2007), 33-63.

xxxiii Gómez Carrillo, 2.

xxxiv Emilio Pisón, 'El prestigio de lo pintoresco'. La Libertad, Sept 12, 1923.

$x x x v$ Ibid.

xxxvi Ibid.

xxxvii Hipólito Finat, 'Turismo retrospectivo' (review of the book Vacaciones en España by Edgar Quinet), La Epoca July 7, 1927, 5.

xxxviii Ibid.

xxxix Anonymous, 'Crónica de la semana', El nuevo mundo, June 18, 1920, 4.

${ }^{x l}$ Anonymous, La Vox, March 18, 1921, 1.

xli Bandolerismo y delincuencia subversiva en la Baja Andalucía (Madrid: Fontanet 1912; facsímile Sevilla: Renacimiento 1992), 51; in 1934, Quirós published with Luis Ardila, El bandolerismo andaluz (Madrid: Gráfica Universal, 1934, 2a ed. Madrid: Turner, 1973).

xlii See, for instance, El espartaquismo agrario andaluz (Madrid: Reus, 1919), one of the sources for Hobsbawm's conceptualization of 'millenarian' rebellions (Primitive Rebels, 74-92).

xliii Quirós 1912, 53.

xliv Ibid.

xlv Anonymous, El Nuevo Mundo, June 18, 1920, 4.

Journal of Tourism History, Vol 6, No. 1 (2014): pg. 38-56. DOI. This article is @ Taylor \& Francis (Routledge) and permission has been granted for this version to appear in e-Publications@Marquette. Taylor \& Francis (Routledge) does not grant permission for this article to be further copied/distributed or hosted elsewhere without the express permission from Taylor \& Francis (Routledge). 
xlvi Ibid.

xlvii Mariano Tomás, 'iYa estamos satisfechos!' iMuchas Gracias! Revista cómico satírica, September 12 1925, 15.

xlviii Ibid. On 'españolada' see Eduardo Rodríguez Merchán, 'De Carmen, la de Triana a La niña de tus ojos: La búsqueda de una armonía estilística de un modelo cinematográfico populista en el transcurso del tiempo', in Metodologías de Análisis del Film; Actas de I Congreso Internacional de Análisis Fílmico, ed. Javier Marzal y Francisco J. Tarín (Madrid: Edip S.A., 2007), 57-76, and Vicente J. Benet y Vicente Sánchez Biosca, 'La españolada en el cine', in Ser españoles: imaginarios nacionalistas en el siglo $X X$, ed. Javier Moreno Luzón and Xosé M. Núñez Seixas (Barcelona: RBA, 2013), 560-91.

xlix Mariano Tomás, id.

I Nelson H. Graburn, Ethnic and Tourist Arts: Cultural Expressions from the Fourth World (Berkeley: University of California Press, 1976).

Ii 'Bandits in Spain', The Times, August 4, 1927, 10.

Iii "No Bandits in Spain'. The Ambassador's Assurance', The Times, August 6, $1927,11$.

liii Ana Moreno Garrido, Turismo y Nación: La definición de la identidad nacional a través de los símbolos turísticos (España 1908-1929), Doctoral Dissertation (Madrid: Universidad Complutense: 2005).

liv Anonymous, 'Carabineros. Prejuicios', La Correspondencia Militar, September $261930,3$.

Iv Anonymous, Gutiérrez, March 31, 1934, 16.

Ivi Ibid.

Ivii The Journal of Tourism History anonymous reviewer remarks that the Franco regime's labeling of Republican maquisards as bandits has a deep legal tradition, dating at least from the Napoleonic wars, and was consistent with the Guardia Civil's practice of labeling rural protesters bandits in the 19th century'.

Iviii As Roman Gubern has pointed out, in foreign film-making throughout the 1930s the general image of Spain remained largely dependent on the romantic stereotypes, 'related to elements either pre-modern (vis-à-vis capitalism and technology) or passional (as opposed to rational)' ('La imagen de España en el cine extranjero', Claves de razón práctica 63 (1996), 74-80). According to Vicente J. Benet, 'the first images of Spain publicized around the world were dominated by local or folkloric references that fascinated contemporary audiences' (El cine español. Una historia cultural, Barcelona: Paidós, 2012). For more on transnational image-making in early Spanish cinema, see Jean-Claude Seguin, 'El cine en la formación de la conciencia nacional', in J.-C. Seguin and Nancy Berthier, eds., Cine, nación y nacionalidades en España (Madrid: Casa Velázquez, 2007), 3-10; Marvin D'Lugo and

Journal of Tourism History, Vol 6, No. 1 (2014): pg. 38-56. DOI. This article is (C) Taylor \& Francis (Routledge) and permission has been granted for this version to appear in e-Publications@Marquette. Taylor \& Francis (Routledge) does not grant permission for this article to be further copied/distributed or hosted elsewhere without the express permission from Taylor \& Francis (Routledge). 
Gerard Dapena, 'Transnational Frameworks', in A Companion to Spanish Cinema, ed. Jo Labanyi and Tatjana Pavlovic (Chichester: WileyBlackwell Publishing Ltd.), 16-47.

lix Qtd. Luis Fernández Colorado, 'Visiones imperiales: documental y propaganda en el cine español (1927-1930)', Actas del VI Congreso de la A.E.H.C. (Madrid: Academia de las Artes y las Ciencias Cinematográficas de España, 1998), 97-110.

Ix KAR-LYNES, 'El cinematógrafo debe ser veraz, moral e instructivo', La Correspondencia de España, July 15, 1922, 4.

Ixi http://elcinematografoilustrado.wordpress.com/2012/06/03/los-siete-ninosde-ecija-o-los-bandidos-de-sierra-morena-h-b-cuesta-1911/.

Ixii Concha Gómez, 'Bandolerismo', Diccionario de Cine Iberoamericano. España, Portugal y América (Madrid: SGAE-Fundación Autor, 2011-12), 651-54. Tomo 1.

Ixiii Ferrán Alberich, 'Armand Guerra', Diccionario del Cine Iberoamericano, España. Portugal y América. (Madrid: SGAE-Fundación Autor, 2011-12), 514-16. Tomo 4.

Ixiv Lisa Jarvinen, The Rise of Spanish-Language Filmmaking: Out from Hollywood's Shadow, 1929-1939 (New Brunswick: Rutgers University Press, 2012), 72-82.

Ixv Ibid., 121-23.

Ixvi Alberto Elena, Cruces de destinos. Intercambios cinematográficos entre España y América Latina, E-excellence, www.liceus.com, 2005, 9.

Ixvii Archivo General de la Administración, Alcalá de Henares, Cultura, Acta November 14, 1929, Fondo 49.2 Caja 12110.

Ixviii María Rosa Cal Martínez and Beatriz Correyero Ruiz, Turismo, la mayor propaganda de Estado: España desde sus inicios hasta 1951 (Madrid, 2008), 167-71.

Ixix 'Correspondencia del presidente del Patronato Sr. Fernández Clérigo', Archivo General de la Administración, Cultura, Fondo 49.2, Caja 12109, Carpeta 3.

Ixx Ibid.

Ixxi Robert Hewison, The heritage industry: Britain in a climate of decline (London: Methuen, 1987); for the debates about 'heritagization' and post-modernity, see Kevin Walsh, The Representation of the Past: Museums and Heritage in the Post-Modern World (London: Routledge, 1992), 68, 138-160; for the link between tourism and heritage, see Melanie K. Smith, Issues in Cultural Tourism Studies (London: Routledge, 2003), 81-86.

Journal of Tourism History, Vol 6, No. 1 (2014): pg. 38-56. DOI. This article is @ Taylor \& Francis (Routledge) and permission has been granted for this version to appear in e-Publications@Marquette. Taylor \& Francis (Routledge) does not grant permission for this article to be further copied/distributed or hosted elsewhere without the express permission from Taylor \& Francis (Routledge). 